POLSKA AKADEMIA NAUK Z ZAKŁAD BADANIA SSAKOW A Vol. V, 14.

\title{
Studies in the Taxonomy of Some Populations of Apodemus sylvaticus (Lin naeus, 1758) in Bulgaria
}

\author{
Badania nad taksonomiką niektórych populacji \\ Apodemus sylvaticus (Li n na e us, 1758) z Bulgarii
}

[With 11 tables and 1 map]

I. Objectives and method of work . . . . . . . . 185

II. Brief data about the places from which the material was collected 186

III. A systematic survey _ . . . . . . . . . . . . . 187

1. Review of literature . . . . . . . . . . . 187

2. A systematic elaboration . . . . . . . . . . . 188

a) Taxonomic characteristics of the population . . . . . 190

b) A variational-statistical comparison with Apodemus sylvaticus sylvaticus . . . . . . . . . . . . . 192

c) A comparison with A. sylvaticus dichrurus . . . . 194

IV. Conclusions _. . . . . . . . . . . . 200

V. Summary . . . . . . . . . . . . . . 200

References . . . . . . . . . . . . . 201

Streszczenie . . . . . . . . . . . . . 201

\section{OBJECTIVES AND METHOD OF WORK}

No studies on the taxonomy of Apodemus sylvaticus (Lin nae us, 1758) in this country have been made up to the present. We find brief data about the biology of this rodent in the papers of Paspalev, Martino \& Peshev (1952), M a rkov (1953; 1954) and Petrov (1954).

The present work aims at giving the taxonomic characteristics of some populations of $A$. sylvaticus in Bulgaria and also at determining their exact systematic position. 
Taxonomic description has been made according to the following somatometric and craniological measurements: length of the hind foot, height of the ear, condylobasal length and zygomatic breadth of the skull. The indices fully characterize the given populations.

Biometric methods have also been used for observations on the data on condylobasal length, zygomatic breadth of the skull and the hind foot. These three indices have also been used as diagnostic of A. sylvaticus.

The following formulas have been used for comparison of the biometric characteristics: for the standard error of the difference between the two means $-\mathrm{m}_{1,2}=\sqrt{\mathrm{m}_{1}{ }^{2}+\mathrm{m}_{2}{ }^{2}}$ and for the maximal error of the difference $-\triangle=t m_{1,2}$. The values of $t$ are calculated in all cases of the 5-per centlevel of significance.

Studies were made of 214 specimens for the following places: "Sherba" State Game-Breeding Farm near the village of Grozdevo, District of Varna - 63; Cherepish Monastery (Balkan Mountains) - 18; Kotel Balkan Mountains (town of Kotel) - 16; District of Sofia (Vitosha and Lozen Mountain) - 38; village of Sreburna, District of Silistra - 39, and Strandja Mountain -40 .

\section{BRIEF DATA ABOUT THE PLACES FROM WHICH THE MATERIAL WAS COLLECTED}

1. „Sherba" State Game-Breeding Farm. It is located southwest of the village of Gorni Chiflik in the Eastern Balkan Mountains. Altitude above sea-level - $150 \mathrm{~m}$. Rocks - sandstones and limestones (Lower Chalk and Upper Jura). Soil - light grey forest, deeply carbonate.

2. Cherepish Monastery. (Western Balkan Mountains in the Isker Gorge). Altitude above sea-level - 240-260 m. Rocks - limestones (Lower Chalk).

3. Town of Kotel. (Kotel Balkan Mountains). Altitude above sea-level about $525 \mathrm{~m}$. Rocks - limestones, marls, claystone (Trias), sandstones, quartzites (Jura). Soil - slightly podzol cinnamon forest; sandy and stony in places.

4. District of Sofia. (Lozen Mountain and the vicinity of the village of Dragalevtsi - (Dragalevski Monastery).

a) Lozen Mountain - Germanski Monastery. Altitude above sea-level $770 \mathrm{~m}$. Rocks - clay-marl limestones, sandstones, conglomerates (Trias and Jura); andesyte and tuffs, clay limestones (Cenozoic); sands, clays and conglomerates (Tertiary). Soil - slightly washed cinnamon forest.

b) Village of Dragalevski - Dragalevski Monastery. Altitude above sealevel - $1040 \mathrm{~m}$. Rocks - andesytes and tuffs (Cenozoic). Soil — slightly podzol cinnamon forest.

5. Village of Sreburna. Situated not far from the town of Silistra. Altitude above sea-level - about $40 \mathrm{~m}$. Rocks - limestones and sandstones (Sarmat); loess (Pleistocene). Soil - alluvial and deluvial meadowy; slightly washed and washed black earth. 
6. Strandja. Altitude above sea-level - 250 to $450 \mathrm{~m}$. Rocks - granodiorytes, granite, marbles, quartzites, sandstones, phyllites (Trias and Jura). Soil - slightly washed and washed cinnamon forest ${ }^{1}$ ).

\section{A SYSTEMATIC SURVEY}

\section{Review of literature}

It is necessary, though very briefly, to glance at the history of the problem formed by the study of systematization of forest mice.

Miller (1912) has accepted that A. sylvaticus and A. flavicollis exist as independent species.

Wettstein (1925) expressed a doubt as to their independence (after M a rtino, 1933), and considered that flavicollis is only a variety of sylvaticus. Eight years later $\mathrm{O}$. Wettstein renounced his former views (We t t s t e in, 1933).

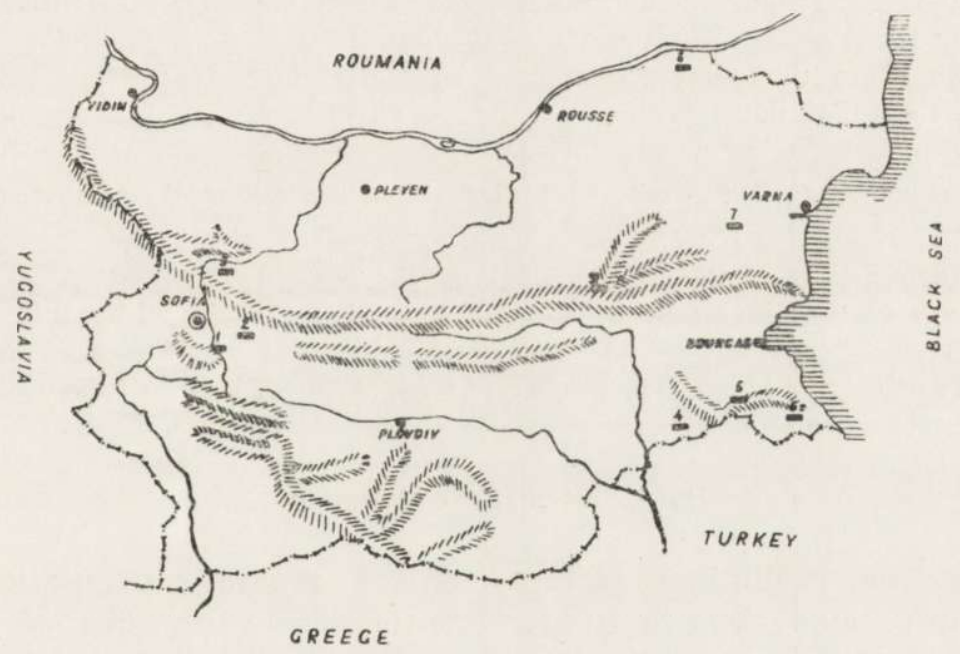

Fig. 1. The place of captures of A. sylvaticus. 1 - Dragalevsky Monastery, 2 - Lozen Mountain, 3 - Cherepish Monastery, 4, 5, 6 - Strandja Mountain, 7 - „Sherba” State Game-Breeding Farm, 8 - Village of Sreburna, 9 - Town of Kotel.

M a rtino (1933), though cautiously, supported Mille r's view by writing: „Nevertheless, it is more probable that Mille r is right that these are two species, since quite young and small specimens of $A$. flavicollis already have a comparatively big foot, which is characteristic of this species".

1) The places of the captures are marked in the map. Data on rock and soil composition are taken from the Soil Atlas of the People's Republic of Bulgaria, Sofia, 1956. 
In $1935 \mathrm{Sch}$ a effer expressed Wettstein's view of 1925 by naming the unique species ,sylvaticus" and accepted ,flavicollis" as an ,ecological race".

Later Zimmermann (1936) and Stein (1938) - (after Heptner, 1940) unequivocally proved the independence of the two species. We have not heard discussions on this problem for a long time. All authors accept the two forms as separate species.

In his work of $1940 \mathrm{Heptner}$ cites a number of authors who admit "transitional" forms between A. sylvaticus and A. flavicollis and he himself reports such "transitional" forms in the Crimea. In our personal correspondence which we had with $\mathrm{Heptner}$ in 1959 , he writes that he maintains his view of 1940 .

Loukina (1957) also mentions that the identification of forest mice in the Caucasus presents great difficulty.

We must mention that in our country specimens occur with combined indices (Sofia District, Kotel, Strandja, etc.) which make it impossible for us to refer them categorically either to the one or to the other species. That is why we share the opinion expressed by Heptner, Loukina a.o. as to the existence of both species and the possibility of cross-breeding between them, thus producing mixed forms.

The specimens with combined indices have not been taken into consideration in the present work.

The complexity of the problem set by the systematic situation of A. sylvaticus is further increased by the great plasticity displayed by this species. This is also borne out by the numerous subspecies and forms of this species described (Miller, 1912; Martino, 1933; Vinogradov \& Gro$\mathrm{mov}, 1952$, a. o.).

\section{A systematic elaboration}

From the preliminary comparison of separate populations of Apodemus sylvaticus in Bulgaria with other subspecies of forest mouse, so far described, it has been established that our specimens are closest to Apodemus sylvaticus sylvaticus (L in na e us, 1788 ) and A. s. dichrurus ( $\mathrm{R}$ a $\mathrm{f}$ i n e s q u e, 1814). This closeness made it necessary to carry out more detailed investigations by comparing the material of $A$. sylvaticus studied with the subspecies $A$. $s$. sylvaticus and $A$. s. dichrurus. On the other hand, we must note that the ranges of these two forms are situated very close to our country.

The comparisons were made on the basis of data supplied by Miller (1912) and Martino (1933). The data on craniological measurements alone are taken from Mille r. He does not give somatometric indices. 


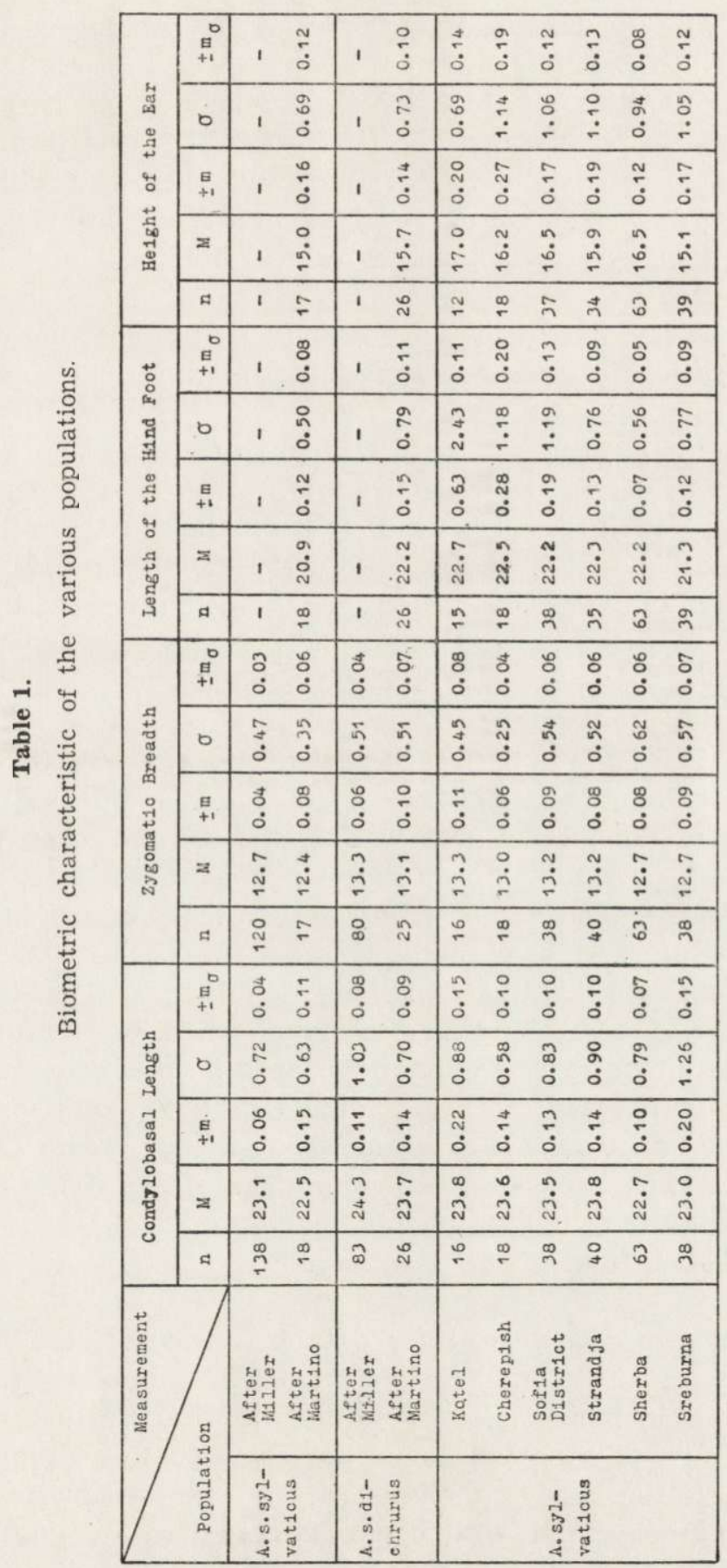


a) Taxonomic characteristics of the population.

In order to differentiate between the taxonomic characteristics of the separate populations, we first established the mean dimension and the mean standard deviation with their respective standard errors $\left(\mathrm{m}_{\mathrm{M}}\right.$ and $\left.\mathrm{m}_{\mathrm{G}}\right)$ on the basis of the indices: condylobasal length, zygomatic breadth, length of the hind foot and height of the ear (Table 1).

While the standard deviation ( $\sigma$ ) gives us the absolute degree of dispersion, the coefficient of variation (V), whose values are given in table 2, indicates the relative degree of dispersion in percentages, makes it possible for us to compare this dispersion in the various populations. In our case the lowest degree of dispersion is displayed by the Cherepish population on the basis of the zygomatic breadth and the highest - by the Kotel population on the basis of the hind foot. The reasons for the differences in the values of $\mathrm{V}$ in the various populations, as well as their explanation, are beyond the scope of our work. These values, however, can be used for comparison with other populations of A. sylvaticus.

The values of Pearson's coefficient of skewness (S) for the degree of asymmetry as given in table 3. Condylobasal length: Specimens of dimensions greater than the typical ones predominate in the populations of $A$. s. sylvaticus after M ille r, and $A . s$. dichrurus after Martino, from Kotel, the Sofia District and Strandja, while specimens of dimensions smaller than the typical ones predominate in the remaining populations. The Cherepish populations exhibit a tendency to symmetrical distribution round the typical dimensions. Zygomatic breadth: Specimens of dimensions greater than typical predominate in the populations of $A$. s. dichrurus after Miller and Martino from Cherepish and Sherba. Specimens of A. s. sylvaticus after Martino are symmetrically distributed in the populations of $A$. sylvaticus after Miller from Kotel, the Sofia District, Strandja and Sreburna:

The situation is analogical for data in respect of the following indices: length of the hind foot and height of the ear.

The results in table 4 also show that we are dealing with populations in which the values of the coefficients of the correlation between the condylobasal length and the zygomatic breadth of the skull are found with comparatively narrow limits (from 
Table 2.

Values of the coefficient of variation $-\mathrm{V}$ (in $\%$ ).

\begin{tabular}{|c|c|c|c|c|c|c|c|c|c|c|}
\hline \multirow{2}{*}{$\underbrace{\text { Population }}_{\text {Weasurement }}$} & \multirow[b]{2}{*}{$\begin{array}{l}\vec{\Xi} \\
\stackrel{0}{0} \\
\simeq\end{array}$} & \multirow{2}{*}{ 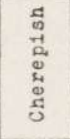 } & \multirow{2}{*}{ 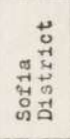 } & \multirow{2}{*}{ 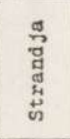 } & \multirow[b]{2}{*}{$\begin{array}{l}\text { हू } \\
\text { है } \\
\text { है }\end{array}$} & \multirow{2}{*}{ 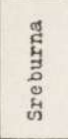 } & \multicolumn{2}{|c|}{ After M1ller } & \multicolumn{2}{|c|}{ After Martino } \\
\hline & & & & & & & $\begin{array}{l}\text { A. s. } \\
\text { sylva- } \\
\text { t1cus }\end{array}$ & $\begin{array}{l}\text { A.s. } \\
\text { dich- } \\
\text { rurus }\end{array}$ & $\begin{array}{l}\text { A.s. } \\
\text { sylva- } \\
\text { t1cus }\end{array}$ & $\begin{array}{l}\text { A.s. } \\
\text { dich- } \\
\text { rurus }\end{array}$ \\
\hline $\begin{array}{l}\text { Condylobasal } \\
\text { length }\end{array}$ & 3.70 & 2.46 & 3.53 & 3.78 & 3.50 & 5.50 & 3.10 & 4.20 & 2.80 & 2.95 \\
\hline $\begin{array}{l}\text { 2ygomat1c } \\
\text { breadth }\end{array}$ & 3.40 & 1.92 & 4.08 & 3.94 & 4.90 & 4.48 & 3.70 & 3.83 & 2.80 & 3.90 \\
\hline $\begin{array}{l}\text { Length of the } \\
\text { hlnd foot }\end{array}$ & 10.70 & 5.25 & 5.36 & 3.41 & 2.50 & 2.77 & - & - & - & 3.56 \\
\hline $\begin{array}{l}\text { He1ght of the } \\
\text { ear. }\end{array}$ & 4.06 & 7.04 & 6.42 & 6.92 & 5.70 & 7.00 & - & - & 4.60 & 4.65 \\
\hline
\end{tabular}

\section{Table 3.}

A comparative table of the degree of asymmetry on the basis of the values of $\mathrm{S}$.

\begin{tabular}{|c|c|c|c|c|c|c|c|c|c|c|}
\hline \multirow{2}{*}{$\begin{array}{r}\text { Population } \\
\text { Xeasurement }\end{array}$} & \multicolumn{2}{|c|}{ After Milier } & \multicolumn{3}{|c|}{ After ilartino } & \multirow{2}{*}{ 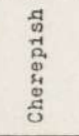 } & \multirow{2}{*}{ 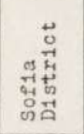 } & \multirow{2}{*}{ 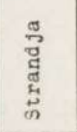 } & \multirow[b]{2}{*}{ 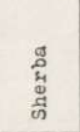 } & \multirow{2}{*}{ 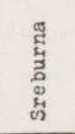 } \\
\hline & $\begin{array}{l}\text { A.s. } \\
\text { sylva- } \\
\text { t1cus }\end{array}$ & $\begin{array}{l}\text { A.s. } \\
\text { dich- } \\
\text { rurus }\end{array}$ & $\begin{array}{l}\text { A.s. } \\
\text { sylva- } \\
\text { t1ous }\end{array}$ & $\begin{array}{l}\text { A.s. } \\
\text { dich- } \\
\text { rurus }\end{array}$ & 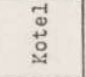 & & & & & \\
\hline $\begin{array}{l}\text { Condylobasal } \\
\text { length }\end{array}$ & +0.42 & -0.58 & -0.95 & +1.00 & +0.67 & 0.00 & +0.60 & +0.33 & -0.51 & -1.13 \\
\hline $\begin{array}{l}\text { Zygomatic } \\
\text { breadth }\end{array}$ & -0.64 & +0.98 & 0.00 & +0.19 & -0.22 & +0.40 & -1.11 & -0.58 & +0.80 & -0.17 \\
\hline $\begin{array}{l}\text { Length of the } \\
\text { hind foot }\end{array}$ & - & - & - & +0.25 & +0.29 & -0.41 & +0.17 & +0.40 & +0.36 & -0.90 \\
\hline $\begin{array}{l}\text { He1ght of the } \\
\text { ear }\end{array}$ & - & - & -0.72 & +0.96 & 0.00 & -0.26 & -0.47 & -0.09 & +0.53 & -0.38 \\
\hline
\end{tabular}

\section{Table 4.}

Coefficients of the co-variation between the condylobasal length and the zygomatic breadth.

\begin{tabular}{|c|c|c|c|c|c|c|c|c|c|}
\hline \multicolumn{2}{|c|}{ After Miller } & \multicolumn{2}{|c|}{ After Martino } & \multirow[b]{2}{*}{$\begin{array}{l}-1 \\
\stackrel{్}{0} \\
\stackrel{g}{\alpha}\end{array}$} & \multirow[b]{2}{*}{ 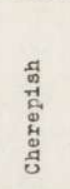 } & \multirow[b]{2}{*}{ 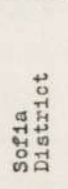 } & \multirow[b]{2}{*}{ 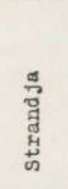 } & \multirow[b]{2}{*}{$\begin{array}{l}\text { कू } \\
\text { ตै } \\
\text { ตี }\end{array}$} & \multirow[b]{2}{*}{ 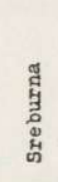 } \\
\hline 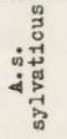 & 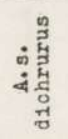 & 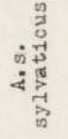 & 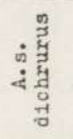 & & & & & & \\
\hline 0.82 & 0.90 & 0.78 & 0.72 & 0.85 & 0.70 & 0.90 & 0.78 & 0.79 & 0.86 \\
\hline
\end{tabular}

0.70 to 0.90 ). These limits give us grounds for thinking that the populations with which we are working belong to one and the same species. The reason for the differences, which are nevertheless observed in the numerical values of the coefficient of the 
correlation in the various populations is probably to be found in the unequal bio-ecological conditions, strictly specific for the individual populations, which have influenced the development of the organisms in general and more particularly the development of the condylobasal and zygomatic bones. In some of the populations - Kotel, Sofia District, Sreburna and after Miller, they have been more favourable and have strengthened the fundamental determinative dependence, and in others - Cherepish, Strandja, Sherba and Yugoslavia, they have decreased it slightly.

The data indicated in table 4 may be used as comparative indices in the description of other populations of $A$. s. sylvaticus and $A$. s. dichrurus. Naturally, the reasons which condition the difference are of a complex character and we could not possibly determine them. This, however, may constitute a subject to be discussed in another work.

The data presented in the preceding tables enable us to form a picture of the separate populations from a taxonomic aspect, on the other hand - to compare these populations according to the respective indices, and finally - to ascertain the purity of the population.

b) A variational-statistical comparison with A. s. sylvaticus.

As shown above, it became necessary to compare the populations studied with the basic form - A. s. sylvaticus, the more so as the preliminary comparisons brought some of our populations closer to it. It is necessary to note, however, that the data on $A$. s. sylvaticus found in the works of $\mathrm{Miller}$ and $\mathrm{Martino}$, according to some measurements (condylobasal length and zygomatic breadth) do not correspond to each other. The specimens from the representative material of Miller show dimensions which are greater than those of $\mathrm{Martino}$ (Table 1).

The differences observed are statistically significant (Table 5). We cannot possibly determine here who of the two authors is right, but these differences made us compare our populations separately with those of Miller and Martino.

The biometric analysis of material from the individual populations, and their comparison with A.s. sylvaticus after the two authors, gave results which divide our populations quite definitely 
Table 5 .

A comparison of A. s. sylvaticus after Mille r (1912) and M a r tino (1933).

\begin{tabular}{|c|c|c|c|c|}
\hline \multirow{2}{*}{ Population } & \multicolumn{3}{|c|}{ Willer - Wartino } & \multirow{2}{*}{ Difference } \\
\cline { 2 - 5 } & $D$ & $\Delta$ & $m_{1,2}$ & significant \\
\hline Condylobasal length & 0.60 & 0.32 & 0.16 & significant \\
\hline Zygomat1c oreadth & 0.30 & 0.18 & 0.09 & \\
\hline
\end{tabular}

Table 6.

A comparison of the Bulgarian populations material with A. s. sylvaticus after Mille $\mathrm{r}(1912)$.

\begin{tabular}{|c|c|c|c|c|c|c|c|c|}
\hline \multirow{2}{*}{$\underbrace{\text { Measurement }}_{\text {Population }}$} & \multicolumn{4}{|c|}{ Condylobasal Length } & \multicolumn{4}{|c|}{ Zygomat1c Breadth } \\
\hline & is & D & $\Delta$ & Difference & u. & D & $\Delta$ & Difference \\
\hline After M111er & 23.1 & & & & 12.7 & & & \\
\hline Kotel & 23.8 & 0.70 & 0.45 & s1gniflcant & 13.3 & 0.60 & 0.24 & significant \\
\hline Cherep1sh & 23.6 & 0.50 & 0.29 & significant & 13.0 & 0.30 & 0.14 & slgnificant \\
\hline Sof1a District & 23.5 & 0.40 & 0.27 & s1gnif1cant & 13.2 & 0.50 & 0.20 & signifloant \\
\hline Strandja & 23.8 & 0.70 & 0.29 & s1gnif1cant & 13.2 & 0.50 & 0.18 & significant \\
\hline Sherba & 22.7 & 0.40 & 0.24 & significant & 12.7 & 0.00 & 0.18 & Insignificant \\
\hline Sreburna & 23.0 & 0.10 & 0.40 & 1ns1gnificant & 12.7 & 0.00 & 0.20 & Insignificant \\
\hline
\end{tabular}

Table 7 .

A comparison of our material with A. s. sylvaticus after M a r tino (1933).

\begin{tabular}{|c|c|c|c|c|c|c|c|c|}
\hline \multirow{2}{*}{$\underbrace{\text { Measurement }}_{\text {Populat1on }}$} & \multicolumn{4}{|c|}{ Condylobasal Length } & \multicolumn{4}{|c|}{ Zygomat1c Breadth } \\
\hline & M & D & $\Delta$ & Difference & M & D & $\Delta$ & Difference \\
\hline After Martino & 22.5 & & & & 12.4 & & & \\
\hline Kotel & 23.8 & 1.30 & 0.55 & s1gnificant & 13.3 & 0.90 & 0.29 & s1.gnif1cant \\
\hline Cherep1sh & 23.6 & 1.10 & 0.43 & s1gnificant & 13.0 & 0.60 & 0.20 & s1gniflcant \\
\hline Sofia D1strict & 23.5 & 1.00 & 0.27 & slgnificant & 13.2 & 0.80 & 0.24 & significant \\
\hline Strandja & 23.8 & 1.30 & 0.42 & s1gnificant & 13.2 & 0.80 & 0.72 & significant \\
\hline Sherba & 22.7 & 0.20 & 0.36 & Insigniflcant & 12.7 & 0.30 & 0.22 & significant \\
\hline Sreburna & 23.0 & 0.50 & 0.50 & 1ns1gnificant & 12.7 & 0.30 & 0.24 & s1gniflcant \\
\hline
\end{tabular}

in two. As shown in table 1 (regarding the values of $\mathrm{M}$ and $\sigma$ ), the specimens in the populations of Kotel, Cherepish, Sofia District and Strandja are bigger than the subspecies A. s. sylvaticus, and the specimens from Sherba and Sreburna are considerably smaller than the compared from after $\mathrm{Mille} \mathrm{r}$ and insignificantly smaller than the Yugoslav ones. According to the indices of condylobasal length and zygomatic breadth of the skull, the 
differences between the materials from Kotel, Cherepish, Sofia District and Strandja, compared with the subspecies A. s. sylvaticus after Miller, are statistically significant (Table 6). The Sherba specimens display a significant difference according to the condylobasal length, and an insignificant one - according to the zygomatic breadth, and those of Sreburna show an insignificant difference according to both measurements.

The results are almost the same also from the comparison of our populations with A. s. sylvaticus of Yugoslavia according to data reported by Martino (1933). The variational-statistical indices ( $\mathrm{M}$ and $\sigma$ ) in table 1 show that the specimens taken from our populations exceed, in their dimensions, those of Yugoslavia. The materials from the populations of Kotel, Cherepish, Sofia District and Strandja, compared to A. s. sylvaticus of Yugoslavia, according to the condylobasal length and zygomatic breadth of the skull, display differences which are great enough to be considered significant, and the materials from Sherba and Sreburna point to insignificant differences according to the index of condylobasal length and to significant ones according to the zygomatic breadth (Table 7).

Comparison of the biometric indices of the central tendency (M) and the degree of dispersion $(\sigma)$, as well as the results obtained from the comparison of our populations with the subspecies $A$. s. sylvaticus after Miller and Martino, shows that the Sherba and Sreburna specimens are medium size, between the two already mentioned, and those in the Kotel, Cherepish, Sofia District and Strandja populations are bigger than these two (Tables 1, 6 and 7$)$.

c) A comparison with A. s. dichrurus.

Our Kotel, Cherepish, Sofia District and Strandja populations, in their dimensions, most closely approach A. s. dichrurus, and this fact necessitated their detailed comparison with this subspecies.

Table 1 itself shows that according to the central tendency (M) and the degree of dispersion $(\sigma)$, the Kotel, Cherepish, Sofia District and Strandja populations approach the subspecies $A$. s. dichrurus whereas the Sherba and Sreburna representatives point to differences. 
The above differences between the materials from our populations and A. s. dichrurus after Miller and Martino prove to be significant for some and insignificant for other populations. Table 8 indicates that the materials from Kotel, Cherepish, Sofia District and Strandja, compared to A. s. dichrurus of Yugoslavia as regards condylobasal length, zygomatic breadth and length of the hind foot, display insignificant differences. The materials from the two remaining populations - Sherba and Sreburna show significant differences in all these dimensions with the length of the hind foot, according to which the Sherba material has proved to be insignificant.

The values which, in their dimensions, are close to $\mathrm{M}$ and $\sigma-$ of the Kotel, Cherepish, Sofia District and Strandja representatives on the one hand and those of $A$. $s$. dichrurus after $\mathrm{Marti-}$ $\mathrm{n} o$ on the other hand (Table 1), point to the subspecific closeness of these populations. Conversely, the significance of the differences in the above indices with respect to the Sherba and Sreburna extractions clearly shows their subspecific difference as compared to A. s. dichrurus (Tables 1 and 8).

The above mentioned double tendency to the subspecific position of our populations is also confirmed by the results obtained from their comparison with $A$. $s$. dichrurus after Miller (Table 9).

We suppose that the differences which are observed between the mean dimensions of some of the measurements in our populations from Cherepish, Sofia District and Strandja are related to the ecological biogeographical rules of $\mathrm{Hinton}$ and Miss B a t e. In accordance with Hinton's rule, which applies to the dependence between the duration of the growth period and the development of the offspring and the dimension of the body measurements, it might be assumed that the specimens of our populations are smaller (and that is why they display significant differences), due to their shorter growth and development period, than the specimens of the population under comparison, which Miller caught in warmer areas in conditions allowing a longer growth period.

Moreover, it is well known that the specimens born early in spring, which have reached sexual maturity, are greater than the specimens also sexually mature but born toward the end of the summer. It is quite possible that in our representative material of 


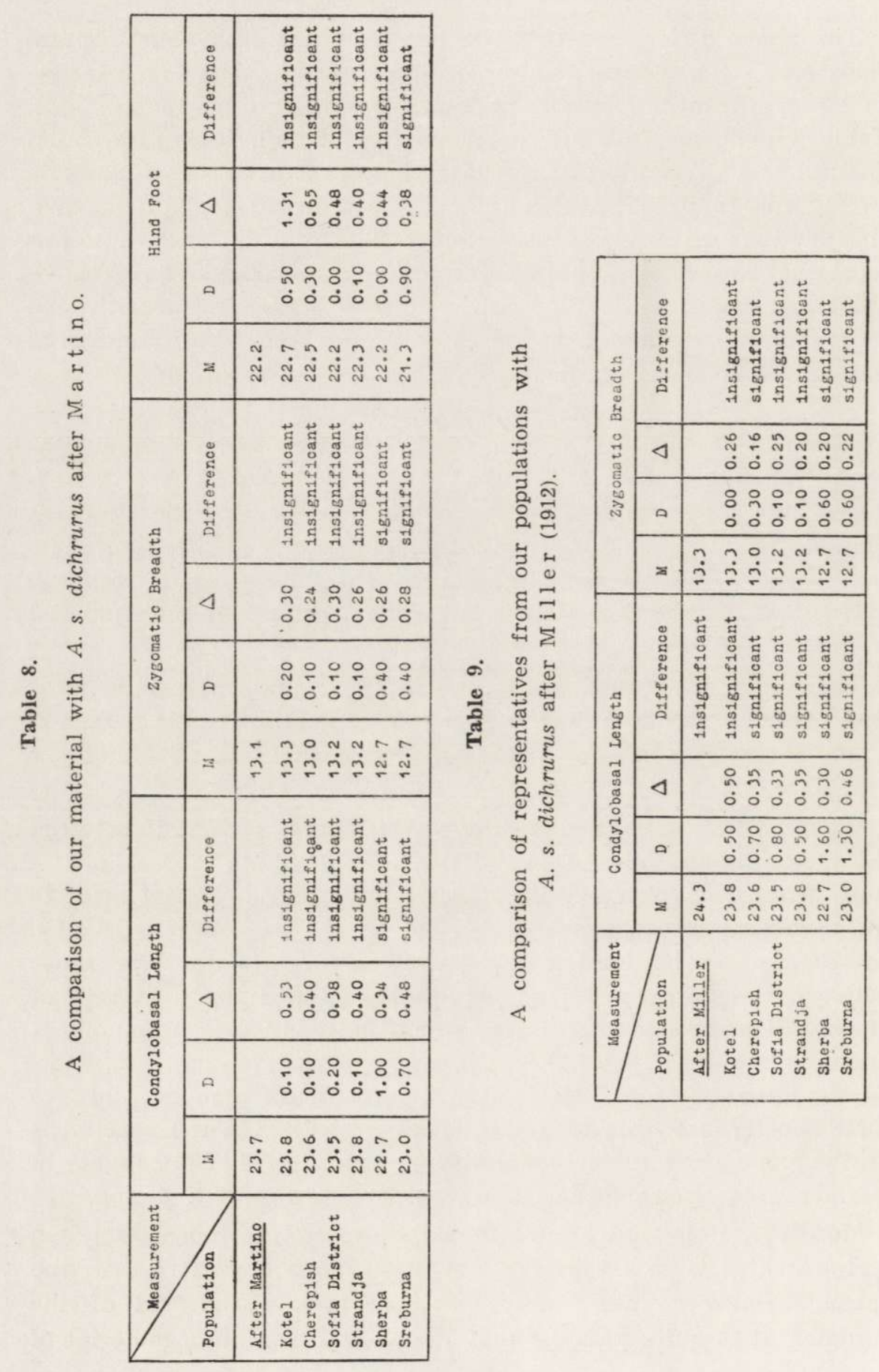


A. sylvaticus there is a greater number of specimens born one or one and a half months before their capture. It is then quite natural that these specimens, though sexually mature, should be smaller than those born two or three months prior to their capture.

Miss B a te's rule about the isolation of the area and the body measurements, according to which the specimens in the smaller area are also of smaller dimensions, may perhaps be applied here to explain the smaller dimensions of the specimens in our populations.

In order to demonstrate that our populations from Cherepish, Sofia District and Strandja belong to the subspecies A. s. dichrurus, despite the significant differences displayed by the respective representatives as compared to the same subspecies after Miller, we must draw attention to table 10 , which gives the results obtained from the comparison between the $A$. s. dichrurus materials of both authors. As shown in the table, the Yugoslav representative

Table 10.

A comparison of A. s. dichrurus populations after Miller and Martino.

\begin{tabular}{|l|c|c|c|c|c|c|c|c|}
\hline Ueasurement & \multicolumn{4}{|c|}{ Condylobasal Length } & \multicolumn{5}{c|}{ Zygomatic Breadth } \\
\cline { 2 - 9 } Population & U & D & $\Delta$ & D1fference & H & D & $\Delta$ & Difference \\
\hline After Mfler & 24.3 & & & & 13.3 & & & \\
After Mart1no & 23.7 & 0.60 & 0.35 & s1gnif1cant & 13.1 & 0.20 & 0.24 & insignificant \\
\hline
\end{tabular}

material displays a significant difference in the condylobasal length of the skull and an insignificant one in the zygomatic breadth, i. e. here again there is no evidence of a complete correspondence between the two populations. These results, however, have not prevented $\mathrm{Martin}$ o from referring his specimens to the subspecies dichrurus. It is quite evident that this has been influenced by the specific bio-ecologic conditions of the two populations.

Due to the fact that the populations of Cherepish, Sofia District and Strandja display an evident closeness to the subspecies $A . s$. dichrurus of Yugoslavia, we accept them as being this subspecies. In this case we attach greater importance and significance to the results from the comparisons of our material with that of Yugoslavia, since our ecological conditions are closer to the Yugoslav ones than to those of the specimens after Miller. Miller's 
data here are used by us as a third, likewise very important dimension, taken as a basis in our comparison as also explaining the inevitable factor in the shape formation - the specificity of the geographic and bio-ecological conditions.

Table 11.

A comparison of representative material from the separate A. sylvaticus populations with that of Kotel (A), Cherepish (B), Sofia District (C), Strandja (D) and Sherba (E).

\begin{tabular}{|c|c|c|c|c|c|c|c|c|}
\hline \multirow{2}{*}{ Populat1on } & \multicolumn{4}{|c|}{ Condylobasal Length } & \multicolumn{4}{|c|}{ Zygomatic Breadth } \\
\hline & u & D & $\Delta$ & Difference & M & D & $\Delta$ & Difference \\
\hline \multicolumn{9}{|c|}{ A } \\
\hline Kotel & 23.8 & & & $\therefore$ & 13.3 & & & \\
\hline Cherepish & 23.6 & 0.20 & 0.53 & Insignificant & 13.0 & 0.30 & 0.26 & significant \\
\hline Sof1a D1strict & 23.5 & 0.30 & 0.50 & Insignificant & 13.2 & 0.10 & 0.28 & ins1gnificant \\
\hline Strand ja & 23.8 & 0.00 & 0.52 & Insignifioant & 13.2 & 0.10 & 0.86 & Ins1gnificant \\
\hline Sherba & 22.7 & 1.10 & 0.48 & significant & 12.7 & 0.60 & 0.28 & significant. \\
\hline Sreburna & 23.0 & 0.80 & 0.60 & significant & 12.7 & 0.60 & 0.28 & significant \\
\hline \multicolumn{9}{|c|}{ B } \\
\hline Cherep1sh & 23.6 & & & & 13.0 & & & \\
\hline Sofia District & 23.5 & 0.10 & 0.38 & 1ns1gn1ficant & 13.2 & 0.20 & 0.22 & Ins1gnifioant \\
\hline Strand ja & 23.8 & 0.20 & 0.40 & 1ns1gnifioant & 13.2 & 0.20 & 0.20 & ins1gnificant \\
\hline Sherba & 22.7 & 0.90 & 0.34 & s1gn1f1cant & 12.2 & 0.30 & 0.20 & signifloant \\
\hline Sreburna & 23.0 & 0.60 & 0.48 & s1gniflcant & 12.7 & 0.30 & 0.22 & s1gniflcant \\
\hline \multicolumn{9}{|c|}{$\mathrm{C}$} \\
\hline Sof1a D1strict & 23.5 & & & & 13.2 & & - & \\
\hline Stranaja & 23.8 & 0.30 & 0.39 & 1nsignificant & 13.2 & 0.00 & 0.24 & ins1gnificant \\
\hline Sherba & 22.7 & 0.80 & 0.34 & significant & 12.7 & 0.50 & 0.24 & signiflcant \\
\hline Sreburna & 23.0 & 0.50 & 0.48 & significant & 12.7 & 0.50 & 0.26 & significant \\
\hline \multicolumn{9}{|c|}{ D } \\
\hline Strandja & 23.8 & & & & 13.2 & & & \\
\hline Sherba & 22.7 & 1.10 & 0.34 & significant & 12.7 & 0.50 & 0.22 & significant \\
\hline Sreburna & 23.0 & 0.80 & 0.49 & significant & 12.7 & 0.50 & 0.24 & s1gniflcant \\
\hline \multicolumn{9}{|c|}{ E } \\
\hline Sherba & 22.7 & & & & 12.7 & & & \\
\hline Sreburna & 23.0 & 0.30 & 0.46 & Insignificant & 12.7 & 0.00 & 0.24 & insignificant \\
\hline
\end{tabular}

All results obtained up till now in the comparison of our materials with the subspecies $A$. s. sylvaticus and $A$. s. dichrurus after Miller and Martino clearly show that the populations from Kotel, Cherepish, Sofia District and Strandja are undoubtedly close 
to the dichrurus subspecies and differ from the sylvaticus subspecies, whereas the Sherba and Sreburna populations more closely approach A. s. sylvaticus and differ from A. s. dichrurus. This clear differentiation of our populations into two groups - one of which coincides with $A$. s. dichrurus and the other approaches $A$. s. sylvaticus - is confirmed by the results obtained from the comparison between our populations themselves. Table 11 (A, B, C and D) show that materials from Kotel, Cherepish, Sofia District and Strandja do not differ essentially from each other, and that they display significant differences as compared with those of Sherba and Sreburna.

The Sherba and Sreburna materials, when compared in respect of the condylobasal length and zygomatic breadth of the skull, show insignificant differences (Table $11 \mathrm{E}$ ).

On the basis of all results so far obtained and indicated in the respective places, we accept that the Kotel, Sofia District and Strandja specimens are one and the same subspecies vis. the subspecies Apodemus sylvaticus dichrurus ( $\mathrm{R}$ a $\mathrm{f}$ in es q u e, 1814).

$\mathrm{Ch}$ a r cteristics. The dimensions are larger than those of A. s. sylvaticus; the hind foot is one the average about $22.3 \mathrm{~mm}$ (22.2-22.7); the condylobasal length of the skull is usually about $23.6 \mathrm{~mm}$ or more (23.5-23.8); the zygomatic breadth is on the average about $13.1 \mathrm{~mm}(13.0-13.3)$. The basic tone of the colour is dark yellow and grey with a predominance of a yellow-rusty shade.

Distribution. At present, this subspecies is established in the following places in Bulgaria: Balkan Mountains (Kotel, Cherepish), Sofia District (Vitosha and Lozen Mountain) and Strandja Mountain.

The distribution of A. s. dichrurus in the Balkan Mountains can be explained by the tectonic relation of this massif across Vitosha and Lyulin Mountain with Kraeshtidité and Ossogovo Mountain, in the eastern parts of which M a r t i n o caught specimens of this subspecies. On the other hand, the relation between the Balkan Mountains and Strandja, through the Bakadjitsité, the St. Ilia and the Monastery Heights explains the distribution of A. s. dichrurus also in Strandja, its range thus acquiring a definite geographic outline. We are impressed by the fact that our A. s. dichrurus populations are encountered at higher altitudes and those of Sherba and Sreburna - in lower places. 
The Sherba and Sreburna populations display a systematic closeness to the subspecies A. s. sylvaticus. It is necessary, however, to deal with populations from other parts of our country also mainly from the Danube Plain, as well as populations for comparison, coming from neighbouring countries, in order definitely to solve the problem connected with the systematic situation of the two other populations mentioned (Sherba and Sreburna). For the present, we have proved their undoubted closeness to $A$. $s$. sylvaticus.

\section{CONCLUSIONS}

1. It has been established that in Bulgaria "transitory" forms occur between Apodemus sylvaticus ( $\mathrm{L}$ innae us, 1758) and Apodemus flavicollis (M elchior, 1834).

2. It has also been established that the A. sylvaticus populations of the Balkan Mountains [Kotel and Cherepish, Sofia District (Vitosha and Lozen Mountain)] and Strandja Mountain belong to the Apodemus sylvaticus dichrurus ( $\mathrm{R}$ a finesque, 1814) subspecies.

3. The systematic closeness of the populations of the "Sherba" State Game-Breeding Farm near the village of Grozdevo, Varna District, and of the village of Sreburna, Silistra District, to the basic Apodemus sylvaticus sylvaticus (Linnaeus, 1759) form has been proved.

\section{S U M M A R Y}

The authors have established that in Bulgaria, as well as in some other countries, "transitory" forms occur between A. sylvaticus (Linnaeus, 1758) and A. flavicollis (M e l chior, 1834).

Employing the methods of variation statistics, the authors have elaborated systematically A.sylvaticus populations of the nine places in Bulgaria (see Fig. 1).

Preliminary comparisons made according to the indices of the taxonomic characteristics of the individual populations show that some of them (Kotel, Cherepish, Sofia District and Strandja) approach the subspecies A.s. dichrurus and others (Sherba and Sreburna) - the basic A. s. sylvaticus form. On this account the populations of Bulgaria under study were compared in detail with the two subspecies indicated. The comparisons were made after Miller (1912) and Martino (1933) on the basis of the condylobasal length, zygomatic breadth and length of the hind foot - indices which are accepted as being diagnostic of A. sylvaticus. 
The comparisons show that the A. sylvaticus populations of Kotel, Cherepish, Sofia District and Strandja belong to the subspecies Apodemus sylvaticus dichrurus ( $\mathrm{R}$ a finesque, 1814) and those of Sherba and Sreburna approach Apodemus sylvaticus sylvaticus (Linnaeus, 1758). The authors do not specify the exact systematic position of the specimens of the last two populations since there is no availab'e material from the remaining part of North Bulgaria (the Danube Plain).

Sofia State University, Sofia, 49, Moskovska Street.

\section{REF ERENCES}

1. Виноградов, Б. С. \& Громов, И. М. 1952. Грызуны ффауны СССР: 1-296, Москва- - Ленинград.

2. Гептнер, В. Г. 1940. Лесные мыши Горного Крыма. Труды Кримского гос. зап., 2. Москва.

3. Лукина, Г. П. 1957. Заметки о мышевидных грызунах и их эктопаразитах в окрестностях озера Јиманчик (Анапский район, Краснодарского края). Уч. зап. Ростовского-на-Дону гос. у-та.

4. М а рков, Г. 1953. Бозайниците в зоната на полезащитните горски пояси в Добруджа. Сп. Природа, 2, 3. София.

5. Марков, Г. 1954. Вредните гризачи и методи на борба с тях. Наръчник за охрана и защита на горите. Земиздат, София.

6. М артино, В. 1033. Прилог систематици и еколошком објашненеу разпростран ена подрода Sylvaemus у Југославији. Зборник радова посвепених живојину Zopneвипу. Београд.

7. Паспалев, Г. В., М артино, К. В. \& Пешев, ц. 1952. Изследвания върху някои дребни гризачи на планината Витоша. Годишник на Соф. университет, 47, 1 - биология.

8. Петров, Б. М. 1954. Проучвания въерху гризачите в Добруджа, тяхното стопанско значение и средства за борба с тях. Списание на научно - изследовательските институти при М-во на земеделието, 2.

9. Mille r, G. 1912. Catalogue of the Mammals of Western Europe, 1-1034, London.

10. Sch a effer, H. 1935. Studien an mitteleuropäischen Kleinsänger mit besonderer Berücksichtigung der Rassenbildung. Arch. f. Naturg., N.F. 4.

11. Wettstein, O, 1933. Beiträge zur Säugetierkunde Europas, III. Z. Säugetierkde, 8, 2. Berlin.

\section{STRESZCZENIE}

W Bułgarii, podobnie jak i w innych krajach, występują formy „przejściowe" między Apodemus sylvaticus (Linnaeus, 1758) a Apodemus flavicollis (M elchior, 1834). 
Autorzy przebadali 214 okazów A. sylvaticus pochodzących z 9 populacji (patrz mapa - Ryc. 1) pod kątem różnic w niektórych wymiarach czasziki (dł. Cb., szerokość jarzmowa) i ciała (długość tylnej stopy), uważanych powszechnie za cechy diagnostyczne dla tego gatunku. W wyniku badań autorzy stwierdzili, że A. sylvaticus łowione w miejscowościach Kotel, Czerepisz i Strandja - należą do podgatunku Apodemus sylvaticus dichrurus (R afinesque, 1814) zaś lowione w Szerba i Sreburna są prawdopodobnie przedstawicielami formy nominantnej, Apodemus sylvaticus sylvaticus (Linnaeus, 1758). Zbyt mały materiał z tych miejscowości i wogóle z Północnej Bułgaril nie pozwala na stwierdzenie tego $\mathrm{z}$ całą pewnością.

\section{BIBLIOTEKA \\ Instytutu Biologii Ssaków \\ Polskiej Akademii Nauk}

$\mathrm{NrCz} .40 .2$

Państwowe Wydawnictwo Naukowe * Warszawa 1961 r. Naklad 1450 egz. Ark. wyd. 1,250. Maszynopis otrzym. 3.VIII.61. Podpis. do druku 13. XI. 1961. Druk ukończono 20. XI. $1961 \mathrm{r}$. Pap. druk. sat. kl. III. 80 gr. Format B-5

Białostockie Zakłady Graficzne. Zam. $3427 *$ B-3 Cena zł 6 